\title{
Assessment of the productive potential and quality of pear fruits of different ripening periods, grown in the south of Russia
}

\author{
T.G. Prichko*, N.V. Mozhar, and N.V. Droficheva \\ Federal State Budget Scientific Institution «North Caucasian Federal Scientific Center of \\ Horticulture, Viticulture, Wine-making», str. 40 Let Pobedy, 39, 350901 Krasnodar, Russia
}

\begin{abstract}
The results of a long-term research on the variety study of 70 pear varieties from the genetic collection of the State Scientific Institution NCFSCHVW of summer, autumn and winter ripening periods, grown in the south of Russia, are presented. Winter-hardy, late-flowering varieties have been identified, which make it possible to reduce the crop losses from frosts and late spring frosts. Highlighted varieties of pears with high yield, valuable for the commercial qualities of the fruit, as well as those distinguished by a high content of sugars, acids, vitamins, which determine the nutritional value and medicinal properties of the fruit.
\end{abstract}

\section{Introduction}

In modern conditions of the economic crisis in the country in agricultural production, many scientists in the direction of restoration of crop production and its subsequent development are considering the transition to the adaptive farming system with elements of energy and resource conservation. The successful development of adaptive breeding of fruit crops is impossible without their extensive ecological testing [1].

In recent years, more and more attention has been paid to the establishment of intensivetype orchards with the use of new varieties, both the breeding of the institute and introduced, of different ripening periods, which, along with the use of modern technological methods of garden cultivation (high planting density, installation of trellis, drip irrigation, etc.) will allow to increase pear fruits yield up to 30 tons per hectare [2].

The variety is one of the most important elements of scientific and technological progress, which ensures the receipt of the largest amount of high-quality products. Taking into account the changing weather conditions both in winter and during the growing season of plants, a reasonable approach to the selection of varieties adapted to local growing conditions is necessary [3-5].

The relevance of research is justified by the great demand for pear varieties in the south of Russia for setting up the intensive-type orchards.

The main purpose of the research is to study the production and biological characteristics of the pear collection fund, which makes it possible to identify new high-yielding varieties with high commercial and taste qualities for replenishing the regional assortment of the region, as well as using them in breeding.

Corresponding author: prichko@yandex.ru 


\section{Materials and methods}

The breeding research was carried out according to the generally accepted programs and methods in the laboratory for the study of varieties and selection of horticultural crops and the laboratory for storage of processing of fruits and berries NCFSCHVW $[6,7]$. In the study of the quality indicators of pear fruits, the following were determined: soluble solids according to GOST ISO 2173-2013 with a digital refractometer PAL-3 (ATAGO); total sugar - by a photometric method on a KFK-3-01 photoelectric colorimeter in accordance with GOST 8756.13-87; titratable acids - by titration in the presence of phenolphthalein indicator in accordance with GOST ISO 750-2013; vitamin C - by the fluorometric method for interaction with o-phenylenediamine with the formation of a fluorescent product according to M 04-07-2010 on "Fluorate-02"; vitamin P - colorimetric method modified by L.I. Vigorov with a vanillin reagent on a KFK-3-01 photoelectric colorimeter. Statistical processing of the results was carried out by using the Microsoft Office Excel program.

The objects of the study were 70 varieties of pears (Pyrus communis L.) of summer, autumn and winter ripening periods, grown at Closed Joint Stock Company (ZAO) Experimental Farm "Centralnoe”, Krasnodar.

\section{Results and discussion}

In order to study, improve and replenish the assortment of pear fruits in the region, a comprehensive assessment of the adaptive and productive potential of pear varieties for different periods of fruit ripening was carried out. As a result, the influence of the environment on the development and growth of plants and their characteristics was analyzed, the varieties were assessed by the main components and their comparative characteristics among themselves and in comparison with the zoned varieties with subsequent individual selection for a complex of economically valuable and adaptively significant traits for specific agroecological conditions.

One of the main directions in the study of pear varieties for the purpose of using it in intensive-type gardens is the study of winter hardiness. This property determines the reaction of pear plants to external environmental conditions, which is controlled by the genetic factors.

In recent years, high early spring temperatures have been observed in the south of Russia, which provoke the premature release of certain varieties from the dormant period. In this regard, fruit buds, and often flowers, were damaged even by minor recurrent frosts.

The growing seasons of 2017-2020 were marked by a significant variety of weather conditions, where spring was characterized by fluctuations from high temperatures $\left(20-25^{\circ}\right.$ $\mathrm{C}$ at the end of March) to frosts (-8-12 ${ }^{\circ} \mathrm{C}$ - mid-April). Considering that the period of flowering of pears in the Krasnodar Territory, according to long-term average data, runs from the second decade of April to the end of the first decade of May, a long period of positive temperatures in winter and in the early spring period provoked an early emergence of trees from dormancy, which led to the damage of fruit buds and more often freezing of generative organs.

In this regard, late-flowering pear varieties are of particular interest in our region. After analyzing the reaction of varieties of the genetic collection of pears to the temperature regime during flowering, the following varieties stood out: Velesa, Williams Stavropolsky, Zaporizhzhya, Zimnyaya Mliyevskaya, Lyuberskaya, the late flowering of which will avoid damage to the generative organs by recurrent frosts and save the harvest.

Evaluation of the pear tree adaptability over a number of years made it possible to identify varieties with the flower resistance to return frosts, which had 10-30\% damage to pistils: introduced varieties - Abbat Fetel, Avgustovskaya rosa, Bere Ardanpon, Devo, Moldavskaya 
early, and varieties of NCFSIHVW selection: Assol', Duet, Zolushka, Iyunskaya rannyaya, Mulatka, Krasnodarskaya Letnyaya, Koketka, Leven, Lyuberskaya, Shikhan.

All selected varieties are of interest for breeding in order to obtain late-flowering varieties and varieties with high resistance of flowers to recurrent frosts, and deserve special attention for production testing.

Productivity is one of the important indicators in the production and biological characteristics of the variety. Its level is determined by the combined effect of soil-climatic and agrotechnical factors. Violation of one of these factors leads to a sharp decrease in yield. As a result, annual yield rates vary considerably.

During the study period, varieties with a productivity higher than $10 \mathrm{t} /$ ha of the NCFSIHVW selection were distinguished: Malyshka (13.5 t / ha), Krasnodarskaya letnyaya (12.4 t / ha), Zolushka (12.1 t / ha), Leven (10.0 t / ha) and introduced varieties: Augustovskaya rosa (10.8 t/ ha) and Moldavskaya early (10.0 t/ ha) (table 1).

Table 1. Productivity of pear varieties (2017-2019)

\begin{tabular}{|c|c|c|c|c|c|}
\hline \multirow{2}{*}{ Variety } & \multicolumn{3}{|c|}{$\begin{array}{c}\text { Average yield over the years, } \mathrm{kg} \\
\text { / tree }\end{array}$} & \multicolumn{2}{|c|}{ Productivity in 3 year } \\
\hline & 2017 & 2018 & 2019 & $\mathrm{~kg} /$ tree & $\mathrm{t} / \mathrm{ha}$ \\
\hline \multicolumn{6}{|c|}{ Summer ripening varieties } \\
\hline Clapp's Favorite (k) & 2,5 & 22,1 & 22,6 & 15,7 & 7,9 \\
\hline Bere Giffard & 2,0 & 11,4 & 35,0 & 16,1 & 8,1 \\
\hline $\begin{array}{l}\text { Krasnodarskaya } \\
\text { Letnyaya }\end{array}$ & 18,0 & 31,3 & 25,0 & 24,1 & 12,4 \\
\hline Sergeyeva early* & 15,0 & 12,3 & 20,0 & 15,8 & 7,9 \\
\hline Moldavian early & 12,0 & 28,0 & 20,0 & 20,0 & 10,0 \\
\hline Williams & 17,5 & 16,0 & 9,7 & 14,4 & 7,2 \\
\hline Malyshka* & 12,0 & 27,5 & 41,5 & 27,0 & 13,5 \\
\hline Augustovskaya rosa & 16,5 & 25,0 & 23,5 & 21,6 & 10,8 \\
\hline Zolushka* & 14 & 31,2 & 27,4 & 24,2 & 12,1 \\
\hline \multicolumn{6}{|c|}{ Autumn ripening varieties } \\
\hline Devo & 6,0 & 15,0 & 25,0 & 15,3 & 7,6 \\
\hline Caucasus & 5,0 & 1,0 & 8,0 & 4,7 & 2,4 \\
\hline Abbot Fetel & 4,0 & 11,2 & 25,0 & 13,4 & 6,7 \\
\hline Lyuberskaya* & 15,0 & 18,0 & 25,0 & 19,7 & 9,8 \\
\hline Bere Clergeau & 3,0 & 12,3 & 20,0 & 11,8 & 5,9 \\
\hline Conference (k) & 2,5 & 33,4 & 9,2 & 15,0 & 7,5 \\
\hline \multicolumn{6}{|c|}{ Winter ripening varieties } \\
\hline Leven * $(\mathrm{k})$ & 16,5 & 18,5 & 25,0 & 20,0 & 10,0 \\
\hline Dzhankoy late & 4,3 & 18,3 & 11,7 & 11,4 & 5,7 \\
\hline Winter Mlievskaya & 4,0 & 17,1 & 16,2 & 12,4 & 6,2 \\
\hline Kieffer & 1,5 & 4,7 & 31,6 & 12,6 & 6,3 \\
\hline$L S D_{05}$ & 1,2 & 1,5 & 1,48 & 0,8 & 1,15 \\
\hline
\end{tabular}

* - varieties of selection SSI NCFSCHVW are highlighted in italics; The varieties in the list are presented as the fruits ripen.

According to the productivity analyzes for the period of 2017-2020, it could be noted that the weather conditions did not allow the biological potential of pear varieties to be fully realized. Due to the presence of return frosts during the flowering of pears, the absence of summer bees, poor maturation of pollen, fruit set in the varieties was noted to be weak, which was especially evident in 2020 , therefore the results of this year were not taken into the account when calculating productivity. 
The problem of improving the industrial assortment of pears, despite the results obtained in the breeding, remains relevant. Therefore, in breeding programs, it is necessary to use the selected sources of economic and biological traits (Table 2).

Table 2. Donors and sources of selectively valuable pear traits

\begin{tabular}{|l|l|}
\hline Traits & \multicolumn{1}{|c|}{ Donor varieties and sources of traits } \\
\hline $\begin{array}{l}\text { Restrained growth and } \\
\text { compactness of the crown }\end{array}$ & $\begin{array}{l}\text { Turquoise, Bere Giffard, Bere Clergeau, Bere Napoleon, } \\
\text { Jacques Tellier, Gervais, Max Red Bartlett, Mallow, } \\
\text { Marguerite Marilla, Dawn }\end{array}$ \\
\hline Early maturity & $\begin{array}{l}\text { Bere Napoleon, Devo, Kieffer, Krasnodarskaya Letnyaya, } \\
\text { Lyuberskaya, Leven, Max Red Bartlett }\end{array}$ \\
\hline Scab resistance & $\begin{array}{l}\text { Kieffer, Kubanskaya sochnaya, Nart, Conference, Devo, } \\
\text { Moldavian early, Osnovyanskaya, Patriotic }\end{array}$ \\
\hline Winter hardiness & $\begin{array}{l}\text { Victoria, Williams, Josephine Mechelnaya, Krasnodarskaya } \\
\text { Letnyaya, Leven, Original }\end{array}$ \\
\hline High yield & $\begin{array}{l}\text { Devo, Conference, Krasnodarskaya Letnyaya, Clapp's } \\
\text { Favorite, Augustovskaya rosa }\end{array}$ \\
\hline High commercial qualities & $\begin{array}{l}\text { Williams, Krasnodarskaya Letnyaya, Conference, Colette, } \\
\text { Kubanskaya pozdnyaya, Leven, Lyuber, Clapp's Favorite, } \\
\text { Pakgam's Triumph, Duet, Samorodok }\end{array}$ \\
\hline
\end{tabular}

In the performance of the work on the variety study, an important direction is the selection of pear varieties with the high commercial qualities of fruits and biochemical indicators that characterize the nutritional value and sources of biologically active substances.

The size of the pear fruits grown in the south of Russia varies widely depending on the variety, the conditions of the year and the load on the trees with the harvest. Based on the results of studies of pear varieties of various ripening periods, genotypes with high and stable technological indicators were identified, regardless of the conditions of the year. These include varieties - Duet, Zolushka, Lyuberskaya, Leven, Samorodok, Bere Ardanpon, Vesnyanka, Moldavanka, Nart, Slavyanka, Cheremshina with a fruit weight of at least $200 \mathrm{~g}$ (Figure 1, Table 2).

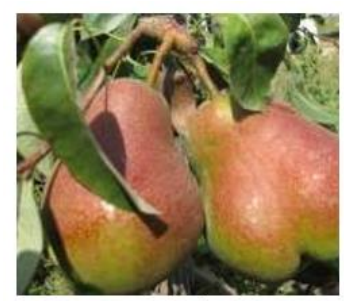

Leven variety

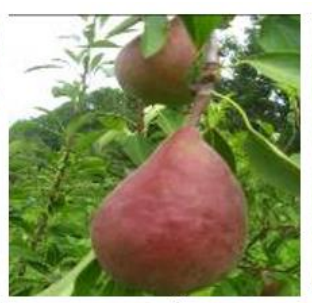

Duet variety

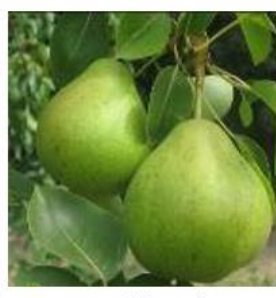

Samorodok variety

Fig. 1. Commercial qualities of pear varieties of selection NCFSIHVW

Table 3. Commercial qualities of pear fruits

\begin{tabular}{|l|c|c|c|c|}
\hline \multirow{2}{*}{ Variety } & \multicolumn{4}{|c|}{ Technical analysis } \\
\cline { 2 - 5 } & weight, $\mathrm{g}$ & height, $\mathrm{mm}$ & diameter, $\mathrm{mm}$ & shape index \\
\hline \multicolumn{5}{|c|}{ Summer ripening varieties } \\
\hline Velesa* & 149,7 & 76,0 & 70,1 & 1,08 \\
\hline Lyuberskaya & 265,0 & 104,8 & 79,3 & 1,25 \\
\hline $\begin{array}{l}\text { Clapp's } \\
\text { Favorite }\end{array}$ & 140,0 & 75,4 & 62,0 & 1,38 \\
\hline Skromnitsa & 175,0 & 88,4 & 64,1 & 1,03 \\
\hline \multicolumn{5}{|c|}{ Autumn ripening varieties } \\
\hline Vesnyanka & 199,0 & 73,7 & 71,4 & \\
\hline
\end{tabular}




\begin{tabular}{|l|c|c|c|c|}
\hline Duet & 254,0 & 90,2 & 72,4 & 1,24 \\
\hline $\begin{array}{l}\text { Krasnokutskaya } \\
\text { osennyaya }\end{array}$ & 145,0 & 73,5 & 53,5 & 1,37 \\
\hline Nart & 345,0 & 100,1 & 83,2 & 1,20 \\
\hline Moldavanka & 196,0 & 87,3 & 70,7 & 1,23 \\
\hline Samorodok & 246,0 & 93,0 & 76,0 & 1,22 \\
\hline Slavyanka & 248,0 & 82,6 & 77,0 & 1,07 \\
\hline \multicolumn{4}{|c|}{ Winter ripening varieties } \\
\hline Bere Ardanpon & 280,0 & 120,0 & 56,0 & 2,14 \\
\hline $\begin{array}{l}\text { Zimnyaya } \\
\text { mliyevskaya }\end{array}$ & 160,0 & 96,4 & 65,4 & 1,47 \\
\hline Leven & 282,0 & 79,2 & 75,4 & 1,05 \\
\hline $\begin{array}{l}\text { Dzhankoyskaya } \\
\text { pozdnyaya }\end{array}$ & 173,0 & 79,5 & 68,1 & 1,17 \\
\hline Cheremshina & 191,0 & 68,6 & 68,0 & 1,01 \\
\hline
\end{tabular}

* - the list of varieties in groups is presented as the fruits ripen

One of the main requirements for the variety is the presence of high palatability of the fruit. The taste and nutritional properties of fruits are largely due to the chemical composition: the content of soluble solids, sugars, acids, vitamins [8-11].

The example of 24 pear varieties shows the variation in the content of sugars, acids and vitamins (table 4). Soluble dry matter (RSV) of pear fruits (12.1-17.9\%) is mainly represented by sugars (7.3-10.8\%). Among the studied varieties of pears, the average content of RSV was $14.4 \pm 0.47 \%$, sugars $-8.7 \pm 0.38 \%$ with a coefficient of variation $(\mathrm{V}=13.8 \%)$. A high level of accumulation of soluble solids is characteristic of varieties of winter ripening (up to $17.9 \%$ ) and sugars (more than $10.8 \%$ ) are noted in varieties: Dzhankoyskaya pozdnyaya, Flamenco, Samorodok, Shikhan, Zimnyaya mlievskaya, Kubanskaya pozdnyaya.

Table 4. Chemical composition of fruits of some pear varieties (average for 2017-2020)

\begin{tabular}{|c|c|c|c|c|c|c|}
\hline Variety & $\mathrm{SS}, \%$ & $\begin{array}{c}\text { Sum of } \\
\text { sugars, \% }\end{array}$ & $\begin{array}{r}\text { Titratable } \\
\text { acidity, \% }\end{array}$ & $\begin{array}{l}\text { Sugar- } \\
\text { acid index }\end{array}$ & $\begin{array}{c}\text { Vitamin } \\
\mathrm{C}, \mathrm{mg} / \\
100 \mathrm{~g}\end{array}$ & $\begin{array}{c}\text { Vitamin P mg } \\
/ 100 \mathrm{~g}\end{array}$ \\
\hline \multicolumn{7}{|c|}{ Summer ripening varieties } \\
\hline June early * & $12,4 \pm 0,21$ & $7,4 \pm 0,13$ & $0,28 \pm 0,02$ & $29,6 \pm 1,45$ & $6,1 \pm 0,30$ & $46,8 \pm 3,59$ \\
\hline Moldavian early & $13,9 \pm 0,25$ & $8,4 \pm 0,20$ & $0,24 \pm 0,02$ & $35,0 \pm 1,60$ & $5,3 \pm 0,34$ & $29,2 \pm 2,01$ \\
\hline Sergeyeva early & $13,0 \pm 0,20$ & $7,8 \pm 0,12$ & $0,39 \pm 0,03$ & $20,0 \pm 1,12$ & $7,2 \pm 0,42$ & $48,5 \pm 3,06$ \\
\hline Clapp's Favorite & $13,2 \pm 0,20$ & $7,9 \pm 0,15$ & $0,36 \pm 0,03$ & $21,9 \pm 1,09$ & $6,2 \pm 0,25$ & $38,8 \pm 2,50$ \\
\hline $\begin{array}{l}\text { Bere } \\
\text { Krasnokutskaya }\end{array}$ & $13,8 \pm 0,31$ & $8,3 \pm 0,15$ & $0,36 \pm 0,02$ & $23,1 \pm 1,30$ & $6,3 \pm 0,50$ & $44,4 \pm 3,80$ \\
\hline Vilena & $13,5 \pm 0,27$ & $8,2 \pm 0,11$ & $0,48 \pm 0,04$ & $16,7 \pm 1,0$ & $6,2 \pm 0,44$ & $34,4 \pm 2,69$ \\
\hline Williams & $13,8 \pm 0,30$ & $8,3 \pm 0,18$ & $0,39 \pm 0,01$ & $20,3 \pm 1,08$ & $5,9 \pm 0,60$ & $42,0 \pm 3,00$ \\
\hline Dachnitsa Kubani & $12,9 \pm 0,20$ & $7,8 \pm 0,10$ & $0,32 \pm 0,03$ & $24,4 \pm 1,40$ & $4,9 \pm 0,40$ & $43,2 \pm 3,08$ \\
\hline Krasulya & $15,4 \pm 0,35$ & $9,8 \pm 0,15$ & $0,27 \pm 0,02$ & $36,2 \pm 2,15$ & $5,1 \pm 0,15$ & $88,8 \pm 4,15$ \\
\hline $\begin{array}{l}\text { Augustovskaya } \\
\text { rosa }\end{array}$ & $12,1 \pm 0,15$ & $7,3 \pm 0,11$ & $0,30 \pm 0,02$ & $24,3 \pm 1,52$ & $6,6 \pm 0,54$ & $25,7 \pm 2,70$ \\
\hline Zolushka & $14,5 \pm 0,29$ & $8,7 \pm 0,18$ & $0,33 \pm 0,03$ & $26,4 \pm 1,35$ & $8,6 \pm 0,64$ & $42,3 \pm 3,05$ \\
\hline Malyshka & $14,1 \pm 0,30$ & $9,1 \pm 0,20$ & $0,29 \pm 0,02$ & $31,8 \pm 1,50$ & $7,9 \pm 0,44$ & $30,1 \pm 3,75$ \\
\hline Flamenco & $15,1 \pm 0,29$ & $9,0 \pm 0,10$ & $0,32 \pm 0,02$ & $28,1 \pm 1,35$ & $6,2 \pm 0,30$ & $45,9 \pm 3,90$ \\
\hline \multicolumn{7}{|c|}{ Autumn ripening varieties } \\
\hline Abbot Fetel & $16,8 \pm 0,35$ & $10,1 \pm 0,15$ & $0,23 \pm 0,02$ & $43,9 \pm 1,75$ & $8,3 \pm 0,65$ & $83,9 \pm 4,15$ \\
\hline Caucasus & $16,0 \pm 0,30$ & $9,6 \pm 0,10$ & $0,36 \pm 0,04$ & $21,7 \pm 1,20$ & $4,8 \pm 0,20$ & $54,9 \pm 4,08$ \\
\hline Lyuber & $14,5 \pm 0,32$ & $8,7 \pm 0,18$ & $0,26 \pm 0,01$ & $33,5 \pm 1,54$ & $5,3 \pm 0,40$ & $28,0 \pm 3,10$ \\
\hline Duet & $13,5 \pm 0,30$ & $8,2 \pm 0,15$ & $0,32 \pm 0,03$ & $25,6 \pm 1,50$ & $6,4 \pm 0,20$ & $36,6 \pm 2,29$ \\
\hline Samorodok & $15,2 \pm 0,35$ & $9,0 \pm 0,20$ & $0,30 \pm 0,01$ & $29,0 \pm 1,35$ & $8,1 \pm 0,52$ & $60,0 \pm 5,98$ \\
\hline \multicolumn{7}{|c|}{ Winter ripening varieties } \\
\hline $\begin{array}{l}\text { Kubanskaya } \\
\text { pozdnyaya }\end{array}$ & $17,9 \pm 0,39$ & $10,8 \pm 0,19$ & $0,45 \pm 0,03$ & $24,0 \pm 1,73$ & $6,8 \pm 0,30$ & $61,4 \pm 5,15$ \\
\hline
\end{tabular}




\begin{tabular}{|l|c|c|c|c|c|c|}
\hline $\begin{array}{l}\text { Zimnyaya } \\
\text { mliyevskaya }\end{array}$ & $16,4 \pm 0,37$ & $9,9 \pm 0,25$ & $0,31 \pm 0,02$ & $31,9 \pm 1,60$ & $7,2 \pm 0,39$ & $70,2 \pm 5,02$ \\
\hline Curé & $12,6 \pm 0,22$ & $7,6 \pm 0,17$ & $0,52 \pm 0,03$ & $14,6 \pm 1,20$ & $5,8 \pm 0,21$ & $65,3 \pm 5,01$ \\
\hline Leven & $13,1 \pm 0,19$ & $7,9 \pm 0,10$ & $0,35 \pm 0,02$ & $27,4 \pm 1,35$ & $8,8 \pm 0,34$ & $64,7 \pm 5,19$ \\
\hline $\begin{array}{l}\text { Dzhankoyskaya } \\
\text { pozdnyaya }\end{array}$ & $15,1 \pm 0,32$ & $9,0 \pm 0,21$ & $0,26 \pm 0,01$ & $37,4 \pm 2,0$ & $8,8 \pm 0,70$ & $69,0 \pm 4,79$ \\
\hline Shikhan & $16,2 \pm 0,33$ & $9,7 \pm 0,15$ & $0,29 \pm 0,03$ & $34,1 \pm 1,55$ & $7,8 \pm 0,54$ & $66,1 \pm 4,19$ \\
\hline
\end{tabular}

* - the list of varieties in groups is presented as the fruits ripen

When studying the fractional composition of sugars from pear fruits of different ripening periods, the prevalence of fructose (5.2-5.64\%) in fruits was established, with a lower content of glucose (1.19-2.53) and sucrose (1.03-1.90\%), which determines the dietary quality of the fruit (Figure 2).

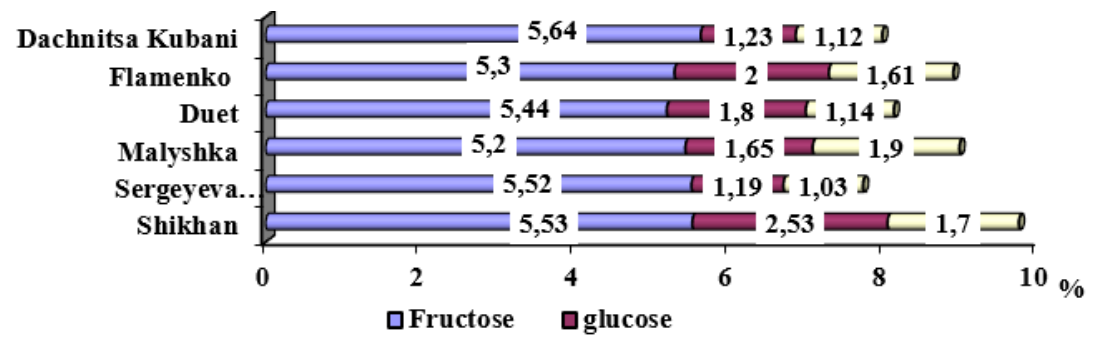

Fig. 2. Fractional composition of pear fruit sugars (for example, varieties of selection of NCFSIHVW)

An important component of the chemical composition of pear fruits, which determines their taste, is organic acids, the content of which, in comparison with the fruits of other crops, is not high - averages is $0.34 \pm 0.02 \%$. Organic acids are represented mainly by malic acid $(0.30 \%)$ with an insignificant citric acid $(0.04 \%)$. The amount of acids in pear fruits, depending on the variety, differs by more than 2.0 times and varies from $0.23 \%$ to $0.52 \%$ (V $=21.1)$. High acidity is characteristic of pear fruits during winter ripening. Acidity from $0.35 \%$ to $0.52 \%$ is characteristic of the varieties such as Clapp's Favorite, Bere Krasnokutskaya, Caucasus, Williams, Sergeeva early, Kubanskaya pozdnyaya, Vilena, Curé. Acids, in relation to sugars, characterize the taste of pear fruits: sweet and sour taste - 14.6 p.u., sweet - 43.9 p.u.

Pear fruits are not a high source of vitamin $\mathrm{C}$, its content in the studied varieties varies from 4.8 to $8.8 \mathrm{mg} / 100 \mathrm{~g}$ with an average value of $6.7 \mathrm{mg} / 100 \mathrm{~g}(\mathrm{~V}=25.1$.). Some varieties: Shikhan, Malyshka, Samorodok, Zolushka, Abbot Fetel, Leven, Dzhankoy pozdnyaya, accumulate an increased amount of vitamin C (7.5-8.8 mg / $100 \mathrm{~g})$.

Varietal differences in the content of vitamin P from 25.7 to $88.8 \mathrm{mg} / 100 \mathrm{~g}$ are strongly expressed, with an average value of $50.6 \pm 5.12 \mathrm{mg} / 100 \mathrm{~g}$ and a high coefficient of variation $(\mathrm{V}=33.9)$. A higher content of vitamin $\mathrm{P}$ is characteristic of the varieties Curé $(65.3 \mathrm{mg} /$ $100 \mathrm{~g})$, Shikhan (66.1 mg / $100 \mathrm{~g})$, Dzhankoy pozdnyaya (69.0 mg / $100 \mathrm{~g})$, Abbot Fetel (83.9 $\mathrm{mg} / 100 \mathrm{~g})$ ), Krasulya (88.8 mg / $100 \mathrm{~g})$.

Based on the research carried out, varieties with a high content of nutrients were identified (table 5)

Table 5. Pear varieties with a high content of macro- and micronutrients

\begin{tabular}{|c|c|}
\hline Indicators & Varieties \\
\hline
\end{tabular}




\begin{tabular}{|c|l|}
\hline \multirow{2}{*}{ Soluble solids $>15 \%$} & $\begin{array}{l}\text { Dzhankoyskaya pozdnyaya*, Flamenko, Samorodok, Konferentsiya, Bere } \\
\text { Napoleon, Devo, Krasulya, Bere Ardanpon, Nikolay Kryuger, Viktoriya, } \\
\text { Caucasus, Melitopol'skaya, Zimnyaya mliyevskaya, Abbat Fetel', Aleksandrin } \\
\text { Dul'yar, Kubanskaya pozdnyaya }\end{array}$ \\
\hline Acids $>0,35 \%$ & $\begin{array}{l}\text { Favorite Klappa *, Bere Krasnokutskaya, Caucasus,Melitopol'skaya, } \\
\text { Williams,Sergeyeva Rannyaya, Krasnodarskaya letnyaya, Kubanskaya } \\
\text { pozdnyaya, Nikolay Kryuger, Kubanskaya sochnaya, Cheremshina, Vilena, } \\
\text { Bere from Turin, Curé }\end{array}$ \\
\hline Vitamin C>7.5 mg / & $\begin{array}{l}\text { Shikhan *, Melitopol'skaya, Devo, Dekanka moldavskaya, Malyshka, } \\
\text { Samorodok, Noyabr'skaya, Victoria, Krasnokutskaya osennyaya, Vesnyanka, } \\
\text { Abbot Fetel, Flora, Zolushka, Cheremshina, Leven, Dzhankoyskaya } \\
\text { pozdnyaya }\end{array}$ \\
\hline Vitamin P $>65 \mathrm{mg} / 100$ & $\begin{array}{l}\text { Curé *, Shikhan, Nikolay Kruger, Alexandrin Douliar, Dzhankoy pozdnyaya, } \\
\text { Yubileynaya, Zimnyaya mliyevskaya, Bere Napoleon, Bere from Turin, Abbot } \\
\text { Fetel, Krasulya }\end{array}$ \\
\hline
\end{tabular}

* - the list of varieties is presented as the quantitative content of nutrients increases

\section{Conclusion}

The conducted studies of pear fruits from the collection of genetic resources NCFSIHVW of different ripening periods make it possible to recommend the selected varieties for use in breeding to create high-quality varieties adapted to growing conditions in the south of Russia.

\section{References}

1. Ye.A. Yegorov, The adaptive potential of horticultural crops in the south of Russia under the stressful temperatures of the winter period, 157 (2006)

2. N.V. Mozhar, International scientific-practical. conf. "Genetic foundations of crop breeding", 210 (2017)

3. T.G. Prichko, Bulletin of Russian Agricultural Science, 3, 39 (2017)

4. Ye.N. Sedov, S.-kh. Biology, 3, 42 (2003)

5. Atlas of the best varieties of fruit and berry crops of the Krasnodar Territory, 104 (2011)

6. Program and methodology for the study of varieties of fruit, berry and nut crops, 606 (1999)

7. Program and methodology for selection of fruit, berry and nut crops, 503 (1995)

8. J. Kolniak-Ostek, Food Chemistry, 203, 491 (2016)

9. X. Li, T. Wang, W.Gao, Nutritional Composition of Pear Cultivars, 573 (2016)

10. T. Ghazouani, W. Talbi, S. Fattouch, Nutritional Composition and Antioxidant Properties of Fruits and Vegetables, 671 (2020)

11. J. Salta, A. Martins, A. P. Rauter, Journal of Functional Foods, 2(2), 153 (2010) 